\begin{tabular}{c} 
Tersedia online di: http://ejournal-balitbang.kkp.go.id/index.php/bawal \\
e-mail:bawal.puslitbangkan@ gmail.com \\
BAWAL WIDYA RISET PERIKANAN TANGKAP \\
Volume 12 Nomor 1 April 2020 \\
p-ISSN: 1907-8226 \\
e-ISSN: 2502-6410 \\
BAWAL \\
Nomor Akreditasi Kementerian RISTEKDIKTI: 21/E/KPT/2018 \\
\hline \hline
\end{tabular}

\title{
IDENTIFIKASI IKAN LIDAH Cynoglossus arel (Bloch \& Schneider, 1801) BERDASARKAN MORFOMETRIK DAN DNA BARCODING YANG DIPERDAGANGKAN DI TEMPAT PELELANGAN IKAN MUARAANGKE
}

\section{IDENTIFICATION OF LARGESCALE TONGUESOLE FISH Cynoglossus arel (Bloch \& Schneider, 1801) TRADED IN MUARA ANGKE FISH AUCTION BASED ON MORPHOMETRIC AND DNA BARCODING}

\author{
Dining Nika Alina*1 dan Hawis H. Madduppa ${ }^{2}$ \\ ${ }^{1}$ Program Studi Magister Ilmu Kelautan, Departemen Ilmu dan Teknologi Kelautan, Fakultas Perikanan dan Ilmu Kelautan, \\ IPB University, Bogor, Indonesia. \\ ${ }^{2}$ Departemen Ilmu dan Teknologi Kelautan, Fakultas Perikanan dan Ilmu Kelautan, IPB University, Bogor, Indonesia \\ Teregistrasi I tanggal: 18 Februari 2020; Diterima setelah perbaikan tanggal: 24 September 2020; \\ Disetujui terbit tanggal: 26 Oktober 2020
}

\begin{abstract}
ABSTRAK
Ikan lidah merupakan ikan ekonomis penting yang menjadi salah satu komoditas yang diperdagangkan di Tempat Pelelangan Ikan (TPI) Muara Angke. Ikan lidah memiliki keunikan karena metamorfosis mereka, kebiasaan membenamkan diri dalam substrat dan sirip pektoralnya yang terdegradasi sedangkan sirip lainnya saling bertemu. Terdapat enam spesies ikan lidah dari famili Cynoglossidae yang dapat ditemukan di Indonesia, sedangkan penelitian terkait identifikasi ikan lidah masih terbatas. Penelitian ini bertujuan untuk mengidentifikasi dan memastikan spesies ikan lidah yang diperdagangkan di TPI Muara Angke berdasarkan pengukuran morfometrik dan DNA Barcoding menggunakan sekuen COI. Hasil analisis morfologi menggunakan literatur menunjukkan bahwa ikan lidah sampel memiliki kemiripan karakteristik morfologi dengan Cynoglossus lingua dan Cynoglossus arel yang kemudian diyakini sebagai $C$. arel berdasarkan ciri diagnostiknya. Berdasarkan analisis DNA barcoding diperoleh spesies Cynoglossus cf. arel dengan identifikasi kesamaan 100\% yang tercantum dalam GenBank. Dari hasil analisis morfologi dan DNA barcoding menunjukkan bahwa ikan lidah yang diperdagangkan di TPI Muara Angke merupakan ikan dari famili Cynoglossidae, genus Cynoglossus, spesies Cynoglossus arel.
\end{abstract}

Kata Kunci: DNA barcoding; Ikan lidah; Morfologi ikan

\section{ABSTRACT}

Tongue Fish Identification Traded in Muara Angke Fish Auction Based on Morphometric and DNA Barcoding Using COI Sequences. Tongue fish is an important economical fish which is one of the commodities traded at Muara Angke Fish Auction. Tongue fish are unique because of their metamorphosis, their habit of immersing themselves in the substrate, and their pectoral fins degraded while the other three fins are confluent. There are six species of tongue fish from the Cynoglossidae family that can be found in Indonesia, whereas the study about tongue fish identifications are limited. The present study aims to identify and clarify the species of tongue fish traded at Muara Angke Fish Auction based on morphometric measurements and DNA Barcoding using the COI sequence. The results of the morphological analysis using the literature showed that the tongue fish samples had similar morphological characteristics with Cynoglossus lingua and Cynoglossus arel which were then believed to be C. arel based on their diagnostic characteristics. DNA barcoding analysis of tongue fish sample shows Cynoglossus cf. arel with 100\% similarity identification listed in GenBank. From the results of morphological analysis and DNA barcoding showed that the tongue fish traded at TPI Muara Angke are fish from the family Cynoglossidae, genus Cynoglossus, species of Cynoglossus arel.

Keywords: Fish morphology; DNA barcoding; Tonguefish

Korespondensi penulis:

e-mail: nikaalina@apps.ipb.ac.id

Telp. +62822-3485-1316

DOI: http://dx.doi.org/10.15578/bawal.12.1.2020.31-39

Copyright $\odot$ 2020, BAWAL WIDYA RISET PERIKANAN TANGKAP (BAWAL) 


\section{PENDAHULUAN}

Tempat Pelelangan Ikan (TPI) Muara Angke terletak di Kelurahan Kapuk Muara, Kecamatan Penjaringan, Kotamadya Jakarta Utara. Tempat pelelangan ini juga merupakan salah satu lokasi Pangkalan Pendaratan Ikan (PPI) terbesar di DKI Jakarta karena besarnya hasil tangkapan yang masuk ke pusat pelelangan. Volume produksi hasil tangkap pada tahun 2015 tercatat sebanyak $34.507 .207 \mathrm{~kg}$ dan mengalami peningkatan hasil produksi ikan sebesar 43,23\% sejak empat tahun kebelakang (Silvia, 2016). Tidak hanya hasil tangkapan yang melimpah, jenis ikan yang diperoleh sangat bervariasi. Jenis ikan hasil tangkapan dominan yang didaratkan di PPI Muara Angke terdiri dari ikan tengiri, ikan layang, ikan lemuru, ikan tembang, dan cumi-cumi (Lubis et al., 2010).

Salah satu jenis ikan komersial yang diperdagangkan di TPI Muara Angke adalah ikan lidah (Cynoglossus sp.) yang dijual dalam keadaan masih segar. Ikan lidah termasuk famili Cynoglossidae dan merupakan ikan demersal, yang hidup di dasar perairan (Jager et al., 1993). Ikan lidah (termasuk kelompok ikan flatfish lainnya) banyak ditemukan di perairan laut dan daerah estuaria dengan substrat berpasir atau pasir berlumpur (Damalas et al., 2009).

Pergerakan ikan lidah adalah pasif sehingga memiliki penyebaran yang tidak terlalu luas dan ikan ini memiliki keunikan metamorphosis yaitu, pada fase larva berbentuk simetri bilateral kemudian saat berkembang ke fase juvenile berubah asimetri bilateral (Kramer, 1991). Keunikan morfologi ikan lidah adalah sirip pektoralnya terdegradasi sedangkan sirip dorsal, sirip anal bertemu atau terhubung dengan sirip kaudal (Munroe, 2001). Kebiasaan ikan lidah adalah membenamkan diri di dalam substrat pada siang hari dan keluar untuk mencari makan di malam hari (Kuiter \& Tonozuka, 2001).

Terdapat setidaknya 6 spesies dari famili Cynoglossidae menurut Munroe (2001) yang dapat ditemukan di Indonesia, yaitu Cynoglossus arel, Cynoglossus bilineatus, Cynoglossus cynoglossus, Cynoglossus lingua, Cynoglossus puncticeps, dan Paraplagusia bilineata. Beberapa spesies memiliki nilai ekonomis penting karena merupakan ikan produksi yang ditangkap dan dikonsumsi oleh masyarakat. Sejauh ini penelitian tentang ikan lidah di Indonesia berhubungan dengan reproduksi biologis (Kamal \& Sunarno, 2017; Zahid \& Simanjuntak, 2009) dan kontaminasi logam berat pada tubuh ikan lidah (Charisma et al., 2014). Penelitian tentang identifikasi spesies ikan lidah komersial secara morfologi dan molekuler masih terbatas di Indonesia. Penentuan spesies ikan tidak hanya dilihat dari bentuk morfologinya saja tapi juga diperlukan pendekatan genetik untuk memastikan telah memperoleh jenis spesies yang tepat.

DNA barcoding telah terbukti berhasil mengidentifikasi berbagai individu hingga tingkat spesies (Dahruddin et al., 2016; Thu et al., 2019). Penelitian dari Madduppa et al. (2017), misalnya telah mengidentifikasi 7 teripang di Kepulauan Seribu, Madduppa et al. (2016) berhasil mengidentifikasi 5 ikan pari yang didapatkan dari Pelabuhanratu, Lampung dan Muara Saban, dan Kim \& Kim (2016) mendapatkan catatan baru munculnya spesies kakap (Lutjanus ophuysenii) di Korea. Melalui berbagai penelitian sebelumnya, DNA barcoding tidak hanya memastikan spesies untuk tujuan identifikasi taksonomi tetapi juga kunci dalam investigasi hasil perikanan (Bingpeng et al., 2018). Berdasarkan hal tersebut, peneliti ingin memastikan spesies ikan lidah yang diperdagangkan di TPI Muara Angke sehingga perlu dilakukan penelitian melalui pendekatan morfologi dan molekuler menggunakan DNA barcoding.

\section{BAHANDANMETODE \\ Pengumpulan dan Identifikasi Sampel}

Sampel ikan lidah didapatkan dari Pasar Ikan Muara Angke, Jakarta yang dibeli langsung dari penjual ikan disana. Sample ikan sebanyak 30 ekor kemudian difoto menggunakan Iphone 6 camera dan diukur secara morfologi dengan tabel pengukuran morfometrik (Boussou et al., 2011) menggunakan jangka sorong. Sampel DNA diambil dari satu spesimen ikan pada jaringan otot sirip kemudian dipreservasi dalam etanol $96 \%$ dan disimpan pada suhu $-20^{\circ} \mathrm{C}$ sebelum dilanjutkan ke tahap ekstraksi DNA. Pada pengukuran morfometrik diperoleh 15 hasil pengukuran (landmark). Karakteristik (landmark) ikan didigitasi kedalam vektor menggunakan CorelDraw $\mathrm{X} 7$ version. 


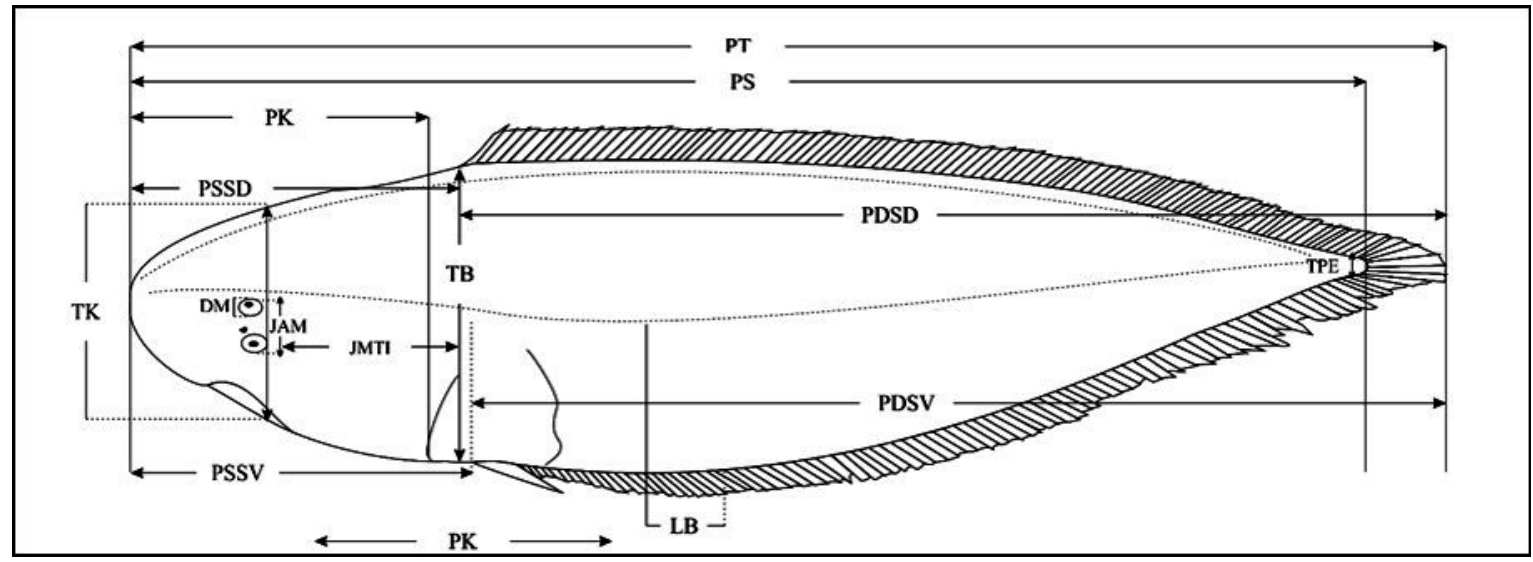

Gambar 1. Karakter morfologi (landmark) yang diukur pada ikan lidah.

Figure 1. Morphological characters (landmark) measured on tongue fish.

\section{Ekstraksi DNA, polymerase chain reaction (PCR) dan sequencing}

DNA genom dari sampel jaringan ikan diekstraksi menggunakan gSYNC ${ }^{\mathrm{TM}}$ DNA Extraction Kit (Geneaid Biotech Ltd., Taiwan), mengikuti prosedur yang tersedia dalam kit. DNA kemudian dielusi dalam volume $50 \mu \mathrm{l}$. Selanjutnya, tahapan amplifikasi PCR gen mitochondrial cytochrome c oxidase subunit I (COI) dilakukan menggunakan primer yang didesain oleh (Ward et al., 2005): FishF1 (5'- TCAACCAACCACAAAGACATTGGCAC-3'); FishR1 (5'- TAGACTTCTGGGTGGCCAAAGAATCA-3'). Reaksi PCR dilakukan dalam volume total $25 \mu$ yang terdiri dari 12,5 $\mu \mathrm{l}$ My taq, 1,25 $\mu 1$ Primer forward dan reverse, $9 \mu \mathrm{lddH} 20$, dan $1 \mu$ l sampel DNA hasil ekstraksi. Kondisi siklus termal dijalankan dalam tahap pradenaturasi 30 detik pada suhu $94^{\circ}$; diikuti oleh 38 siklus denaturasi $\left(94^{\circ} \mathrm{C}, 30\right.$ detik), anneling $\left(50^{\circ} \mathrm{C}\right.$, 60 detik), elongasi $\left(72^{\circ} \mathrm{C}, 60\right.$ detik); dan elongasi akhir pada suhu $72^{\circ} \mathrm{C}$ selama 7 menit. Hasil PCR dikumpulkan dan diperiksa kualitasnya melalui elektroforesis dengan gel agarose 1,0\% (110 $\mathrm{V}$, selama 20 menit). Agarose diwarnai dengan GelRedTM (Biotium®) dan diamati dibawah UV transilluminator. Hasil amplifikasi selanjutnya dikirim ke The 1st BASE® di Singapura untuk dilakukan analisis sekuensing.

\section{Analisis Data}

Analisis data dilakukan secara morfologi dari hasil identifikasi morfologi dan pengukuran morfometrik sedangkan secara molekuler digunakan hasil sekuensing DNA. Morfologi ikan lidah diidentifikasi menggunakan informasi yang tersedia di FAO (Munroe, 2001) dan buku Fish Market (White et al., 2013). Hasil pengukuran morfometrik ikan lidah dianalisis menggunakan hubungan panjang dan berat. Hubungan panjang-berat dihitung untuk menyelidiki pola pertumbuhan ikan lidah menggunakan persamaan berikut menurut Froese et al., (2011); Le Cren (1951):

$\mathrm{W}=\mathrm{aPT}^{\mathrm{b}}$
Diubah dalam regresi linier:

$\log (\mathrm{W})=\log (\mathrm{a})+\mathrm{b} \log (\mathrm{PT})$

Dimana:

$\mathrm{W}=$ berat tubuh ikan (gram)

PT = panjang total tubuh ikan $(\mathrm{mm})$

$\mathrm{a} \quad=$ intersep persamaan regresi

$\mathrm{b}=$ slope persamaan regresi

Ekponen b adalah koefisien pertumbuhan yang mencerminkan tingkat pertumbuhan relatif dari dua variabel yang digunakan. Konstanta a merupakan nilai dari sumbu Y ketika nilai $X$ sama dengan 1. Jika nilai $b=3$, maka pola pertumbuhan bersifat isometrik, yaitu pertambahan bobot setara dengan pertumbuhan panjang ikan, namun jika nilai $b \neq 3$, maka pola pertumbuhannya bersifat alometrik, yaitu alometrik positif apabila nilai $b>3$ (ikan menjadi lebih berat karena pertambahan bobot lebih cepat dibandingkan dengan pertambahan panjang) dan allometrik negatif apabila $b<3$ (ikan menjadi lebih ramping karena pertambahan panjang lebih cepat dibandingkan dengan pertambahan bobot). Hasil perhitungan hubungan panjang-berat ikan lidah kemudian dibandingkan terhadap data di FishBase.

Analisis molekuler dilakukan berdasarkan hasil sekuensing DNA yang diproses menggunakan software MEGA6.0 (Tamura et al., 2013). Urutan basa yang muncul kemudian diselaraskan urutannya pada database Gene Bank melalui situs NCBI dan dibandingkan dengan urutan referensi yang tersedia.

\section{HASIL DAN BAHASAN Hasil}

Karakteristik morfologi sampel ikan lidah yang diperdagangkan di TPI Muara Angke, Jakarta disajikan di Gambar 2. 


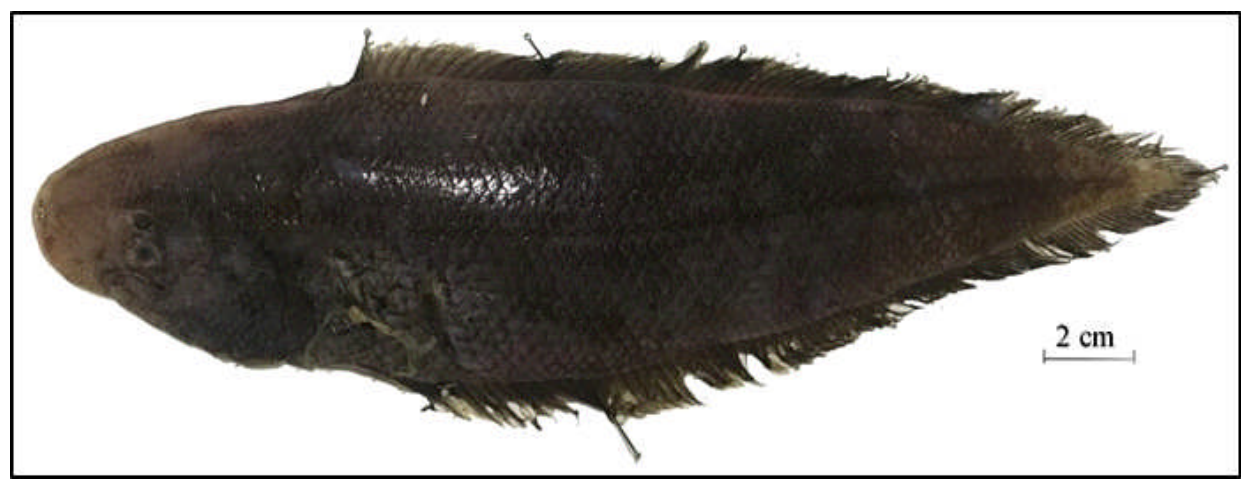

Gambar 2. Morfologi ikan lidah yang diperdagangkan di TPI Muara Angke.

Figure 2. Tongue fish morphology traded in Muara Angke Fish Auction.

Ikan lidah (tongue fish) yang diperdagangkan di TPI Muara Angke merupakan ikan dari famili Cynoglossidae, genus Cynoglossus. Terdapat kesamaan ciri morfologi dalam satu genus tersebut yang membuatnya sulit diidentifikasi hanya berdasarkan pengamatan saja. Di Indonesia terdapat 6 spesies ikan lidah antara lain, Cynoglossus arel, Cynoglossus bilineatus, Cynoglossus cynoglossus, Cynoglossus lingua, Cynoglossus puncticeps, dan Paraplagusia bilineata (Munroe, 2001). Dari enam spesies tersebut $C$. arel dan $C$. lingua adalah yang terdekat kemiripannya dengan ikan lidah sampel dilihat dari ciri morfologi berupa warna tubuh, bentuk tubuh, posisi mata dan rasio panjang tubuhnya.

Pengukuran morfometrik dilakukan pada 30 ekor ikan lidah sampel dan didapat 15 landmark dan berat badan ikan sampel yang sudah dirata-rata. Dari hasil pengukuran tersebut diperoleh hubungan panjang-berat untuk mengetahui pola pertumbuhan ikan lidah. Berikut adalah hasil pengukuran morfometrik ikan lidah sampel.

Tabel 1. Hasil pengukuran morfometrik ikan lidah dan standar deviasi

Table 1. Morphometric measurement of tongue fish and standard deviation

\begin{tabular}{lll}
\hline Landmark & Pengukuran (cm) & Standar Deviasi (cm) \\
\hline PT (Panjang total) & 26.16 & \pm 1.83 \\
PS (Panjang standar) & 25.13 & \pm 1.83 \\
PK (Panjang Kepala) & 5.21 & \pm 0.49 \\
TK (Tinggi Kepala) & 4.99 & \pm 0.38 \\
TB (Tinggi Badan) & 6.21 & \pm 0.42 \\
TPE (Tinggi pangkal ekor) & 0.49 & \pm 0.14 \\
DM (Diameter mata) & 0.45 & \pm 0.81 \\
JAM (Jarak antara dua mata) & 0.23 & \pm 0.06 \\
LB (Lebar Badan) & 1.20 & \pm 0.28 \\
PSSV (Panjang sebelum sirip ventral) & 6.09 & \pm 0.97 \\
PSSD (Panjang sebelum sirip dorsal) & 26.13 & \pm 1.92 \\
PSSA (Panjang sebelum sirip anal) & 20.25 & \pm 2.11 \\
PDSV (Panjang dasar sirip ventral) & 20.24 & \pm 2.12 \\
PBE (Panjang batang ekor) & 0.5 & \pm 0 \\
JMTI (Jarak mata ke tutup insang) & 2.62 & \pm 0.31 \\
\hline
\end{tabular}

Diperoleh data panjang total (PT) rata-rata $26,16 \pm 1,83$ $\mathrm{cm}$ yang diukur dari ujung depan kepala hingga ke belakang sirip ekor. Adapun berat rata-rata ikan sampel adalah 90,77 $\pm 16,59$ gr. Berdasarkan kedua data tersebut diperoleh hubungan panjang-berat ikan lidah yaitu $\mathrm{W}=$ $0,0653 \mathrm{PT}^{2,2135}$ dengan $\mathrm{R}^{2}=0,7421$ dan persentase $\mathrm{R}^{2}$ adalah $74,2 \%$ (Gambar 3). Hasil perhitungan tersebut kemudian dibandingkan dengan data di Fishbase (Tabel 2). 


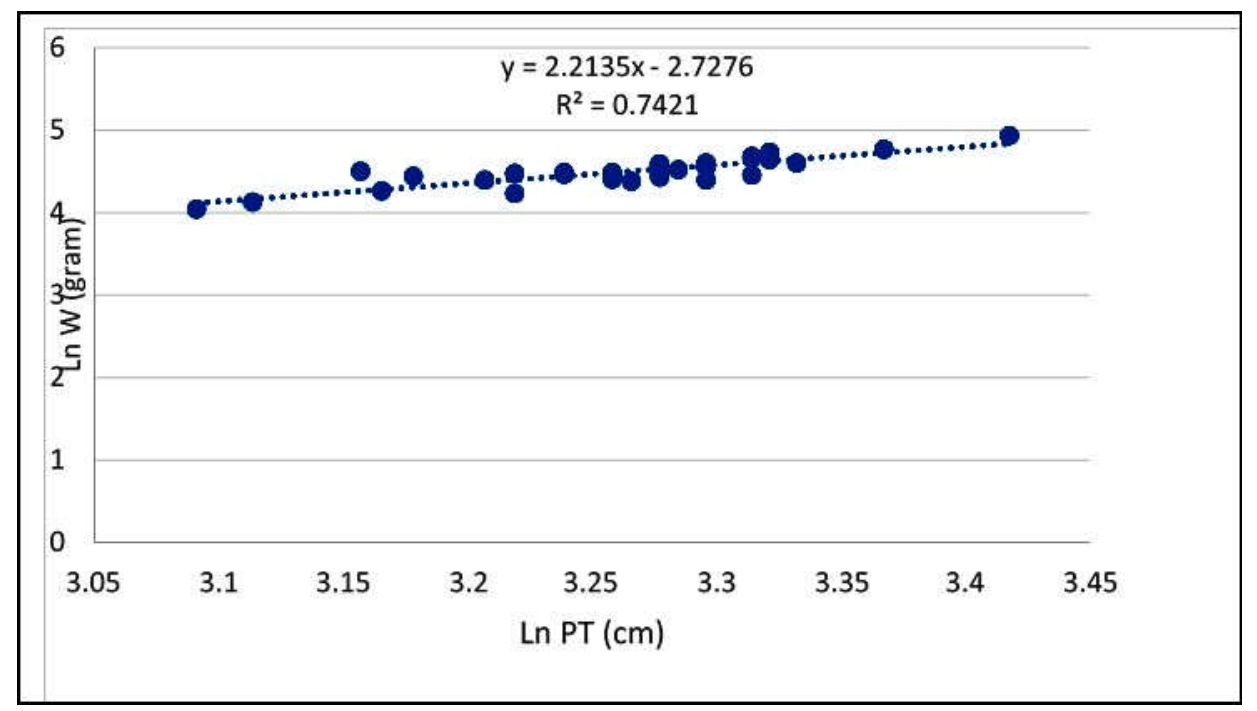

Gambar 3. Grafik hubungan panjang-berat sampel ikan lidah.

Figure 3. Graphic of length-weight relationship of tongue fish sample.

Tabel 2. Parameter hubungan panjang-berat $C$. arel dari hasil pengukuran dan dalam FishBase

Table 2. $\quad$ Parameter of length-weight relationship C. arel from measurement result and data on FishBase

\begin{tabular}{|c|c|c|c|c|c|c|c|}
\hline Species & $\mathbf{a}$ & b & Score & $\mathbf{r}^{2}$ & $\mathbf{n}$ & Country & Location \\
\hline $\begin{array}{l}\text { Cynoglossus } \\
\text { arel }\end{array}$ & 0.0653 & 2.213 & & 0.742 & 30 & Indonesia & $\begin{array}{l}\text { Muara Angke Fish } \\
\text { Auction }\end{array}$ \\
\hline $\begin{array}{l}\text { Cynoglossus } \\
\text { arel }\end{array}$ & 0.00111 & 3.415 & 0.5 & & & India & Off Cochin \\
\hline $\begin{array}{l}\text { Cynoglossus } \\
\text { arel }\end{array}$ & 0.00781 & 2.912 & 0.83 & 0.826 & 651 & India & $\begin{array}{l}\text { Porto Novo }\left(11 \hat{\mathrm{A}}^{\circ} 29{ }^{\prime} \mathrm{N}\right. \\
\left.79 \hat{\mathrm{A}}^{\circ} 46^{\prime} \mathrm{E}\right), 1981-82\end{array}$ \\
\hline $\begin{array}{l}\text { Cynoglossus } \\
\text { arel }\end{array}$ & 0.0035 & 3.089 & 0.95 & 0.95 & 2619 & $\begin{array}{l}\text { Hong } \\
\text { Kong }\end{array}$ & $\begin{array}{l}\text { western, southern and } \\
\text { eastern waters of Hong } \\
\text { Kong / 2012-2016 }\end{array}$ \\
\hline
\end{tabular}

Berdasarkan hasil analisis DNA Barcoding menggunakan fragmen gen cytochrome c oxidase subunit I (COI), diperoleh panjang DNA 675bp. Analisis barcode DNA gen COI pada sampel ikan yang diperdagangkan di TPI Muara Angke kemudian dilanjutkan dengan mencocokkan data di GenBank NCBI dengan Request ID: Z7FVBVPG014. Berdasarkan hasil analisis tersebut setelah dibandingkan dengan database GenBank NCBI

Tabel 3. Hasil BLAST basa nukleotida pada GenBank.

Table 3. Result BLAST of nucleotide base at GenBank. didapatkan tingkat kemiripan tertinggi dimiliki oleh spesies Cynoglossus arel dengan Max score dan total score yang sama yaitu 1186, query cover $95 \%, E$ (Expect) value 0.0 dan Ident $100 \%$. Sekuen Bank gen yang paling mirip dicirikan dengan nilai Max Score dan Total Score sama, Query Coverage mendekati $100 \%$, E value mendekati 0, dan Ident mendekati $100 \%$ pada setiap database (Triandiza \& Madduppa, 2018) (Tabel 3).

\begin{tabular}{lllllll}
\hline Deskripsi & $\begin{array}{l}\text { Max } \\
\text { Score }\end{array}$ & $\begin{array}{l}\text { Total } \\
\text { Score }\end{array}$ & $\begin{array}{l}\text { Query } \\
\text { cover }\end{array}$ & $\begin{array}{l}\text { E } \\
\text { value }\end{array}$ & $\begin{array}{l}\text { Per. } \\
\text { iden }\end{array}$ & Nomor Aksesi \\
\hline $\begin{array}{l}\text { Cynoglossus cf. arel FOAL255- } \\
\text { 10 voucher BW-A9904 }\end{array}$ & 1186 & 1186 & $95 \%$ & 0.0 & $100 \%$ & $\underline{H Q 956067.1}$ \\
$\begin{array}{l}\text { cytochrome oxidase subunit 1 } \\
\text { (COI) gene, partial cds; }\end{array}$ & & & & & & \\
mitochondrial & & & & & & \\
$\begin{array}{l}\text { Cynoglossus itinus voucher } \\
\text { MBCSC:Z711088 cytochrome } \\
\text { oxidase subunit I (COI) gene, } \\
\text { partial cds; mitochondrial }\end{array}$ & 1182 & 1182 & $95 \%$ & 0.0 & $99.84 \%$ & EU595086.1 \\
\hline
\end{tabular}


Alina, D.N \& H.H. Madduppa/BAWAL. 12 (1) April 2020: 31-39

\begin{tabular}{lllllll}
\hline $\begin{array}{l}\text { Cynoglossus arel voucher } \\
\text { USNM:444135 cytochrome } \\
\text { oxidase subunit 1 (COI) gene, } \\
\text { partial cds; mitochondrial }\end{array}$ & $\mathbf{1 1 7 0}$ & $\mathbf{1 1 7 0}$ & $\mathbf{9 5 \%}$ & $\mathbf{0 . 0}$ & $\mathbf{9 9 . 5 3 \%}$ & $\underline{\mathrm{MH} 235627 .}$ \\
\hline $\begin{array}{l}\text { Cynoglossus arel voucher } \\
\text { USNM:444134 cytochrome } \\
\text { oxidase subunit 1 (COI) gene, } \\
\text { partial cds; mitochondrial }\end{array}$ & 1164 & 1164 & $95 \%$ & 0.0 & $99.38 \%$ & $\underline{\mathbf{M}}$ \\
$\begin{array}{l}\text { Cynoglossus lingua voucher } \\
\text { ISGMM7 cytochrome oxidase } \\
\text { subunit 1 (COI) gene, partial } \\
\text { cds; mitochondrial }\end{array}$ & 682 & 682 & 95 & 0.0 & 85.83 & $\underline{1}$ \\
\hline
\end{tabular}

\section{Bahasan}

Secara morfologi ikan lidah yang diperdagangkan di TPI Muara Angke memiliki ciri yang mirip antara spesies Cynoglossus lingua dan Cynoglossus arel. Dari hasil pengukuran morfometrik diperoleh persentase tinggi badan (TB) dibanding panjang standar ikan (PS), yaitu $23,7 \%$ yang sesuai dengan persentase $C$. arel yaitu $20-$ $26 \%$. Di sisi lain, $C$. lingua tidak masuk dalam persentase tersebut karena berkisar $17-22 \%$ dan memiliki bentuk tubuh yang sangat panjang. Berdasarkan karakteristik moncong ikan lidah sampel berbentuk meruncing bukan membulat seperti yang dimiliki ikan lidah lainnya, $C$. bilineatus, C. cynoglossus, dan C. puncticeps (Menon, 1977; Munroe, 2001). Perbedaan lainnya adalah warna tubuh ikan lidah sampel yang mirip dengan $C$. arel yang memiliki warna tubuh coklat yang hampir seragam sedangkan $C$. lingua berwarna coklat kemerahan dengan bercak gelap terutama di penutup insang (Munroe, 2001; White et al., 2013).

Ciri diagnostik lain dari $C$. arel adalah badan memanjang, persentase tinggi dibanding panjang standar adalah 20 hingga 26\%. Mata dengan ruang interorbital bersisik kecil. Moncongnya berbentuk meruncing; kait rostral pendek; sudut mulut mencapai posterior ke atau di luar mata bawah, sekitar pertengahan antara pembukaan insang dan ujung moncong. Jumlah sirip bagian dorsal: sirip anal: sirip ekor berturut-turut adalah 116-130: 85-98: 10 (Munroe, 2001). Terdapat dua gurat sisi pada sisi tubuh yang bermata; namun tidak muncul pada sisi tak bermata. Sisik pada garis midlateral berjumlah 56-70. Sisik berukuran besar dengan sisik yang bergerigi di sisi yang bermata dan bulat di sisi tak bermata; 7-9 deret sisik antara kedua gurat sisi pada sisi tubuh yang bermata. Vertebra total yang dimiliki antara 50-57. Ikan berwarna coklat seragam pada sisi bermata dengan bercak gelap yang terdapat pada penutup insang dan berwarna putih di sisi tak bermata (White et al., 2013).
Pengukuran morfometrik dilakukan untuk dapat mengetahui variasi morfologis suatu spesies yang mungkin berbeda karena faktor lingkungan dan genetik (Herath et al., 2014). Dari hasil pengukuran morfometrik ikan sampel $C$. arel, panjang total yang diperoleh adalah $26.16 \pm 1.83 \mathrm{~cm}$. Ukuran tersebut relatif lebih pendek dibandingkan parameter asymptotic length, panjang ratarata ikan dalam stok jika mereka tumbuh untuk periode yang sangat panjang, yang didata selama 1997 - 1998 di Teluk Northwest Arabian yaitu 35,2 cm (Mohamed et al., 2002).

Hal tersebut dikuatkan dengan data dalam FishBase untuk ikan $C$. arel yang memiliki pertumbuhan panjangberat hampir sebanding (isometrik). Ikan sampel yang didata dalam FishBase berasal dari India dan Hong Kong sehingga ada faktor geografis yang mempengaruhi pola pertumbuhan ikan (Tabel 2). Sebagai perbandingan lain, penelitian ikan C. arel di Teluk Persian, Iran mendapatkan kisaran total panjang tubuh $11-33 \mathrm{~cm}$ pada betina dan 10 $31 \mathrm{~cm}$ pada jantan (H. Ghaffari et al., 2015; Hamze et al., 2011). Perbedaan pertumbuhan tersebut tidak hanya karena letak geografis tetapi juga faktor lingkungan yang mempengaruhi fenotip suatu individu (Ramadhaniaty et al., 2018). Selain itu, pada area dengan tingkat eksploitasi yang tinggi akan membentuk populasi ikan dengan pertumbuhan yang lebih kecil (Kamal \& Sunarno, 2017). Hal tersebut berkolerasi karena ikan yang diperdagangkan di TPI Muara Angke berasal dari perairan Teluk Jakarta yang telah banyak mendapat tekanan lingkungan.

Perhitungan hubungan panjang-berat dapat juga menjadi parameter untuk mengetahui stok dan populasi ikan (Karna et al., 2018). Berdasarkan perhitungan hubungan panjang-berat diperoleh nilai b $\hat{A} 3$ yang artinya, pertambahan panjang ikan lidah lebih cepat dibandingkan dengan pertambahan bobotnya yang dapat dilihat dari ukuran tubuhnya yang ramping namun panjang. Jenis pertumbuhan tersebut adalah allometrik negatif (Le Cren, 
1951). Nilai $R$ yang diperoleh adalah 0,7421 menunjukkan bahwa ada hubungan sangat erat antara panjang-berat dan $74,2 \%$ pertambahan bobot tubuh ikan terjadi karena pertambahan panjang tubuhnya.

Berdasarkan pendekatan molekuler, DNA Barcoding adalah metode dalam taksonomi molekuler menggunakan urutan DNA pendek untuk mengidentifikasi suatu spesies. Umumnya kode sandi DNA target untuk hewan tingkat tinggi adalah sekuen dalam mitokondria sitokrom oksidase subunit 1 atau dikenal sebagai CO1 (Madduppa et al., 2017). Sekuen COI inilah yang sering digunakan untuk identifikasi ikan dan dibuktikan telah mampu mengidentifikasi sepuluh spesies dari genus Cynoglossus yang didapat dari Spanyol, Mozambik, Bangladesh dan Korea (Noh et al., 2016). Dari hasil BLAST di situs NCBI diperoleh spesies Cynoglossus arel dengan persentase kesamaan basa $100 \%$ dan nilai Query cover $95 \%$, yaitu persentase kedekatan sekuen yang dianalisis dengan sekuen yang dimiliki oleh spesies yang tercantum. Adapun, spesies yang secara morfologi memiliki kemiripan dengan spesies $C$. arel yaitu $C$. lingua memiliki persentase kemiripan identifikasi hanya $85 \%$ dengan sampel ikan.

\section{KESIMPULAN}

Hasil analisis morfologi dan DNA barcoding secara keseluruhan menunjukkan bahwa spesimen ikan lidah yang diperdagangkan di TPI Muara Angke merupakan ikan dari famili Cynoglossidae, genus Cynoglossus, spesies Cynoglossus arel.

\section{PERSANTUNAN}

Penelitian ini dapat dilakukan atas bantuan dan fasilitas dari Laboratorium Biosistematika Kelautan dan Biodiversitas, Institut Pertanian Bogor (BIODIVSI-IPB) dan segenap tim dari kelase IKL2019 yang memberi bantuan dan membersamai dalam pengambilan data. Untuk itu, penulis menyampaikan terima kasih.

\section{DAFTAR PUSTAKA}

Bingpeng, X., Heshan, L., Zhilan, Z., Chunguang, W., Yanguo, W., \& Jianjun, W. (2018). DNA barcoding for identification of fish species in the Taiwan Strait. PLoS ONE, 1-13. Retrieved from https://doi.org/10.1371/ journal.pone.0198109

Boussou, C. K., Konan, F. K., Edia, E. O., Ouattara, M., Bony, Y. K., Ouattara, A., \& Gourène, G. (2011). Morphometric analysis of populations of Chromidotilapia guntheri (Sauvage, 1882) (Cichlidae, perciformes) in four coastal rivers of côte d'Ivoire (West Africa). Pan-American Journal of Aquatic Sciences, 5(3), 387-400.
Charisma, A. M., Irawan, B., \& Soegianto, A. (2014). Contamination of $\mathrm{Pb} \mathrm{Cd} \mathrm{Cu} \mathrm{Zn} \mathrm{in} \mathrm{black} \mathrm{pomfret} \mathrm{Formio}$ niger and tongue sand Cynoglossus lingua fish caught from the western part of Madura strait and its safe limits consumption. Journal of Biological Researches, 18(2), 102-105. https://doi.org/10.23869/ bphjbr.18.2.20135

Dahruddin, H., Hadiaty, R. K., \& Hubert, N. (2016). DNA barcoding: foundations and applications for southeast asian freshwater fishes. Treubia, 43(December), 1-16.

Damalas, D., Katsanevakis, S., Maravelias, C. D., \& Karageorgis, a. P. (2009). habitat selection of flatfish in relation to spatial, temporal and environmental parameters in the Aegean sea. In 9th Symposium on Oceanography \& Fisheries, 2009 - Proceedings, Volume ÉÉ, 1(4), 777-782.

Froese, R., Tsikliras, A. C., \& Stergiou, K. I. (2011). Editorial note on weight-length relations of fishes. In Acta Ichthyologica et Piscatoria, 41(4), 261-263. https:// doi.org/10.3750/AIP2011.41.4.01

Ghaffari, H., Hosseinzadeh Sahafi, H., Engelhard, G. H., \& Mekhanik Babaei, M. (2015). Reproductive biology of largescale tonguesole Cynoglossus arel in coastal waters of Bandar Abbas, Persian Gulf, Iran. Animal Reproduction Science. https://doi.org/10.1016/ j.anireprosci.2014.12.004

Ghaffari, Hamze, Ardalan, A. A., Sahafi, H. H., Babaei, M. M., \& Abdollahi, R. (2011). Annual changes in gonadosomatic index (GSI), hepatosomatic index (HIS) and condition factor $(\mathrm{K})$ of largescale tonguesole Cynoglossus arel (Bloch \& Schneider, 1801) in the coastal waters of Bandar Abbas, Persian Gulf. Australian Journal of Basic and Applied Sciences, 5(9), 1640-1646.

Herath, H., Radampola, \& K. Herath, S. (2014). Morphological variation and length weight relationship of Oreochromis mossambicus in three brackish water systems of southern. International Journal of Research in Agriculture and Food Sciences, 2(2), 11-22. https://doi.org/10.13140/ 2.1.1369.9207

Jager, F., Kleef, H. L., \& Tydeman, P. (1993). The distribution of 0-group flatfish in relation to abiotic factors on the tidal flats in the brackish Dollard (Ems Estuary, Wadden Sea). Journal of Fish Biology, 43, 31-43.

Kamal, M. M., \& Sunarno, M. T. D. (2017). Biological Reproductive of Estuarine Fish Comparing Between Demersal (Long Tongue Sole, Cynoglossus lingua) 
and Pelagical: (Mutached thryssa, Thryssa mystax) Assemblages. Indonesian Fisheries Research Journal, 15(2), 37-42. https://doi.org/10.15578/ ifrj.15.2.2009.37-42

Karna, S. K., Sahoo, D. K., Seth, J. K., Mohapatro, D., Rout, A. K., Panda, S., \& Guru, B. C. (2018). Lengthweight relationship of three Cynoglossus species $(C$. puncticeps, C. lingua and C. lida) from Chilika lagoon, India. Journal of Applied Ichthyology, 34(4), 988-989. https://doi.org/10.1111/jai.13603

Kim, H. N., \& Kim, J. K. (2016). New record of Spotstripe snapper, Lutjanus ophuysenii (Perciformes: Lutjanidae) from Korea. Fisheries and Aquatic Sciences, 19(43), 1-5. https://doi.org/10.1186/s41240016-0043-7

Kramer, S. (1991). The shallow-water flatfishes of San Diego County. California Cooperative Oceanic Fisheries Investigations Reports, 32(3), 128-142.

Kuiter, R. H., \& Tonozuka, T. (2001). Indonesian Reef Fishes (p. 780). Part 3. Eels to Snappers. Australia: Zoonetics.

Le Cren, E. D. (1951). The Length-Weight Relationship and Seasonal Cycle in Gonad Weight and Condition in the Perch (Perca Fluviatilis). Journal of Animal Ecology, 20(11), 201-219. Retrieved from https:// www.jstor.org/stable/1540

Lubis, E., Wiyono, E. S., \& Nirmalanti, M. (2010). Penanganan Selama Transportasi Terhadap Hasil Tangkapan Didaratkan di Pelabuhan Perikanan Samudera Nizam Zachman: Aspek Biologi dan Teknis. Jurnal Mangrove Dan Pesisir, X(2), 1-7.

Madduppa, H., Ayuningtyas, R. U., Subhan, B., Arafat, D., \& Prehadi. (2016). Exploited but unevaluated: DNA Barcoding reveals skates and stingrays (Chordata, Chondrichthyes) species landed in the Indonesian fish market. ILMU KELAUTAN: Indonesian Journal of Marine Sciences, 21(1), 29-36. https://doi.org/ 10.14710/ik.ijms.21.1.29-36

Madduppa, H., Taurusman, A. A., Subhan, B., Anggraini, N. P., Fadillah, R., \& Tarman, K. (2017). Short communication: DNA barcoding reveals vulnerable and not evaluated species of sea cucumbers (Holothuroidea and Stichopodidae) from Kepulauan Seribu reefs, Indonesia. Biodiversitas, 18(3), 893-898. https://doi.org/10.13057/biodiv/d180305

Menon, A. G. K. (1977). A systematic monograph of the tongue soles of the genus Cynoglossus Hamilton-
Buchanan (Pisces: Cynoglossidae). Smithsonian Contributions to Zoology, (238), 1-129. https:// doi.org/10.5479/si.00810282.238

Mohamed, A. M., Ali, T. S., \& Hussain, N. A. (2002). Stock condition of large-scale tongue sole, Cynoglossus arel, in the northwest Arabian Gulf. Marina Mesopotamica, 17(October), 1-12.

Munroe, T. A. (2001). Bony fishes part 4 (Labridae to Latimeriidae), estuarine crocodiles, sea turtles, sea snakes and marine mammals. In The living marine resources of the Western Central Paciûc (vol. 6, pp. 3890-3901). Rome: FAO.

Noh, E. S., Kang, H. S., An, C. M., Park, J. Y., Kim, E. M., \& Kang, J. H. (2016). Rapid and Specific Identification of Genus Cynoglossus by Multiplex PCR Assays Using Species-specific Derived from the COI Region. Journal of Life Science, 26(9), 1007-1014. Retrieved from http:/ /dx.doi.org/10.5352/JLS.2016.26.9.1007

Ramadhaniaty, M., Setyobudiandi, I., \& Madduppa, H. H. (2018). Morphogenetic and population structure of two species marine bivalve (Ostreidae: Saccostrea cucullata and Crassostrea iredalei) in aceh, Indonesia. Biodiversitas, 19(3), 978-988. https://doi.org/10.13057/ biodiv/d190329

Silvia, L. (2016). Peluan Peningkatan Kelas Pangkalan Pendaratan Ikan Muara Angke, Jakarta Utara [skripsi]. Bogor (ID): Institut Pertanian Bogor

Tamura, K., Stecher, G., Peterson, D., Filipski, A., \& Kumar, S. (2013). MEGA6: Molecular evolutionary genetics analysis version 6.0. Molecular Biology and Evolution, 30(12), 2725-2729. https://doi.org/10.1093/ molbev/mst197

Thu, P. T., Huang, W. C., Chou, T. K., Van Quan, N., Van Chien, P., Li, F., ... Liao, T. Y. (2019). DNAbarcoding of coastal ray-finned fishes in Vietnam. PLoS ONE, 14(9), 1-13. https://doi.org/10.1371/journal.pone.0222631

Triandiza, T., \& Madduppa, H. (2018). Aplikasi Analisa Morfologi dan DNA Barcoding pada Penentuan Jenis Kepiting Porcelain (Pisidia sp.) yang Berasal dari Pulau Tunda, Banten. Jurnal Sumberdaya Akuatik Indopasifik, 2(November), 81-90.

Ward, R. D., Zemlak, T. S., Innes, B. H., Last, P. R., \& Hebert, P. D. N. (2005). DNA barcoding Australia's fish species. Philosophical Transactions of the Royal Society B: Biological Sciences, 360(1462), 1847-1857. https://doi.org/10.1098/rstb.2005.1716 
BAWAL. 12 (1) April 2020: 31-39

White, W. T., Last, P. R., Dharmadi, Faizah, R., Chodrijah, U., Prisantoso, B. I., ... Blaber, S. J. M. (2013). Market Fish of Indonesia (p. 342-343). Canberra: Australian Centre for International Agricultural Research (ACIAR).
Zahid, A., \& Simanjuntak, C. P. H. (2009). Biologi Reproduksi dan Faktor Kondisi Ikan Ilat-Ilat, di Perairan Pantai Mayangan, Jawa Barat. Jurnal Iktiologi Indonesia, 9(1), 85-95. 